\title{
EFFECT OF CONAGENIN ON THROMBOCYTOPENIA INDUCED BY ANTITUMOR AGENTS IN MICE
}

\author{
Masaji Kawatsu, Takashi Yamashita, Masaaki Ishizuka* \\ and TOMIO TAKEUCHI \\ Institute for Chemotherapy, M.C.R.F., \\ 18-24 Motono, Miyamoto, Numazu, Shizuoka 410-03, Japan
}

(Received for publication May 19, 1994)

\begin{abstract}
The effect of conagenin ( $\mathrm{CNG}$ ) on myelosuppression induced by antitumor agents was investigated. The daily administration of CNG prevented reduction in the number of platelets (PLT) observed in peripheral blood of mice given mitomycin $\mathrm{C}(10 \mathrm{mg} / \mathrm{kg})$ but did not prevent reduction in the number of leukocytes (WBC). The effect on PLT was also confirmed in mice given cyclophosphamide $(100 \mathrm{mg} / \mathrm{kg})$. In mice given repeated doses of 5 -fluorouracil $(10 \mathrm{mg} / \mathrm{kg}), \mathrm{CNG}$ prevented the reduction of PLT as well as WBC and maintained them at normal levels. CNG prevented reduction of the production of interleukin-2, 3 and 6 in cultured supernatants of spleen cells taken from mice given 5-fluorouracil.

These results suggest that CNG modulates production of lymphokines which are responsible for thrombopoiesis.
\end{abstract}

It is known that myelosuppression induced by antitumor agents is one of the limiting factors for cancer chemotherapy. Although granulocyte colony-stimulating factor (G-CSF) and granulocytemacrophage colony-stimulating factor $(\mathrm{GM}-\mathrm{CSF})$ has been applied to restore leukocytes $(\mathrm{WBC})^{1 \sim 4)}$, there are, except for some cytokines, no agents to restore platelets (PLT). The reduction in PLT seen with cancer chemotherapy can be fatal. Although cytokines like interleukin (IL)-1 ${ }^{2,4)}$, IL-3 ${ }^{5,6)}$, IL-6 ${ }^{4,7 \sim 11)}$ and stem cell factor $(\mathrm{SCF})^{12 \sim 15)}$ can restore PLT, systemic administration of those cytokines can result in severe toxicity. We set out to find a low molecular weight immunomodulator produced by microorganisms which stimulates the production of WBC and PLT by induction of cytokines ${ }^{16 \sim 21)}$. We found that conagenin (CNG) prevents reduction of PLT in peripheral blood of mice given antitumor agents ${ }^{22}$.

$\mathrm{CNG}$, an immunomodulator which binds exclusively to $\mathrm{T}$ cells activated by concanavalin $\mathrm{A}$ or cytokines, and augments production of lymphokines and $\mathrm{T}$ cell proliferation ${ }^{23,24)}$, was found in metabolites of Streptomyces roseosporus (Fig. 1).

We report here the effect of CNG on prevention reduction of WBC and PLT in mice given antitumor agents.

\section{Materials and Methods}

Mice

$\overline{\mathrm{CDF}}_{1}$ and $\mathrm{C} 57 \mathrm{BL} / 6$ mice $(5 \sim 6$ weeks old, female) were purchased from Charles River Japan Inc. (Kanagawa, Japan) and were maintained under specific pathogen-free conditions at $23 \pm 2^{\circ} \mathrm{C}$ and $55 \pm 5 \%$ humidity. They were employed for experiments at 6 to 7 weeks of age. Each experimental group consisted of 6 to 8 mice.
Fig. 1. Structure of CNG.

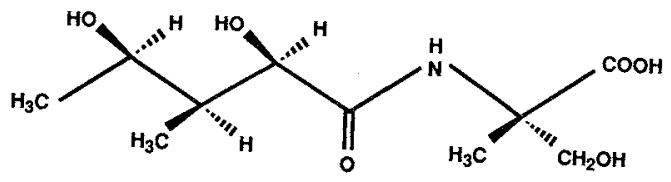

Produced by: Streptomyces roseosporus Molecular formula: $\mathrm{C}_{10} \mathrm{H}_{19} \mathrm{NO}_{6}$ Molecular, weight: 249.26 
Conagenin and Other Chemicals

Conagenin (CNG) was prepared by KANEKA Co. Ltd. (Osaka, Japan) according to the procedures reported previously ${ }^{23)}$. Mitomycin C (MMC; Kyowa Hakko Kogyo Co. Ltd., Tokyo, Japan), cyclophosphamide (CY; Shionogi \& Co. Ltd., Osaka, Japan) and 5-fluorouracil (5-Fu; Kyowa Hakko Kogyo Co. Ltd., Tokyo, Japan) were used as antitumor agents. For experiments, these drugs were dissolved in sterilized saline.

Determination of the Number of WBC and PLT in Peripheral Blood of Mice Given CNG with or without Antitumor Agents

Mice were given $\mathrm{CNG}$ with or without antitumor agents in schedules indicated in the figures. Peripheral blood was collected by puncture of retro-orbital venous plexus and the number of WBC and PLT was counted by a Coulter counter (Japan Scientific Instruments Co. Ltd., Tokyo, Japan).

Assessment of Lymphokine Production by Spleen Cells and Bone Marrow Cells

The effect of CNG on lymphokine production by lymphoid cells of mice was assessed as follows: $\mathrm{CNG}$ at $5 \mathrm{mg} / \mathrm{kg}$ was administered ip on days 0 to 15 starting on the day given antitumor agents, 5-Fu at $100 \mathrm{mg} / \mathrm{kg}$ was administered ip to C57BL/6 mice on days 0,4 and 8 . Spleen cells and bone marrow cells of the femur were prepared from treated mice and $1 \mathrm{ml}$ of each cell preparation at $5 \times 10^{6} \mathrm{cells} / \mathrm{ml}$ in RPMI1640 (Nissui Seiyaku Co. Ltd., Tokyo, Japan) containing 10\% heat inactivated fetal calf serum was plated, then incubated at $37^{\circ} \mathrm{C}$ in $5 \% \mathrm{CO}_{2}$ for 1 hour. Non-adherent cells in the plate were collected and each preparation at $1 \times 10^{7}$ cells $/ \mathrm{ml}$ was incubated in RPMI 1640 supplemented $10 \%$ heat inactivated fetal calf serum, $50 \mu \mathrm{M}$ 2-mercaptoethanol, non essential amino acids, $1 \mu \mathrm{M}$ sodium pyruvate, $50 \mathrm{units} / \mathrm{ml}$ penicillin and $50 \mu \mathrm{g} / \mathrm{ml}$ streptomycin at $37^{\circ} \mathrm{C}$ in $5 \% \mathrm{CO}_{2}$ for 3 days. After incubation, the cultured supernatants were collected, and interleukin(IL)-2, IL-3 or IL-6 levels in the supernatants were determined by ELISA. ELISA kit for IL-2 was purchased from Becton Dickinson Labware (Bedford, U.S.A.) and for IL-3 and IL-6 were from Endogen Inc (Boston; U.S.A.).

Statistical Analysis

Results are shown as the mean \pm standard deviation. The statistical significance of the data was analyzed by Student's $t$-test.

\section{Results}

Effect of CNG on Restoration of WBC and PLT

in Mice Given Antitumor Agents, MMC, CY and 5-Fu

The effect of CNG on restoration the number of WBC and PLT in peripheral blood of mice given antitumor agents was investigated.

$\mathrm{CDF}_{1}$ mice were given $10 \mathrm{mg} / \mathrm{kg}$ of $\mathrm{MMC}$ once and $5 \mathrm{mg} / \mathrm{kg}$ of CNG daily for 28 days and the number of WBC and PLT was monitored. Four days after the administration MMC significantly reduced the WBC counts which recovered by day 8 (Fig. 2a). CNG prevented the reduction on day 4 . On the other hand, the number of PLT was not affected at day 4 but markedly reduced in $80 \%$ by MMC alone from days 8 to 24 and the reduction was prevented by the administration of CNG (Fig. 2b).

The effect of CNG on PLT was confirmed in mice given repeated doses of CY. CDF 1 mice were given $100 \mathrm{mg} / \mathrm{kg}$ of $\mathrm{CY}$, every other day for 7 times and $5 \mathrm{mg} / \mathrm{kg}$ of CNG daily for 16 days beginning the day of first CY administration, and the number of WBC and PLT in peripheral blood were monitored. In this model, CNG could not prevent the reduction of WBC (Fig. 3a). The number of PLT was reduced within 4 days and continued low up to day 16. Although CNG could not prevent the reduction seen on day 4, it restored the number of PLT on day 8 and this effect was observed up to day 16 (Fig. 3b).

The effect of CNG in mice given 5-Fu was investigated. C57BL/6 mice were given $100 \mathrm{mg} / \mathrm{kg}$ of 5 -Fu 
Fig. 2. Effect of CNG on WBC and PLT in mice given mitomycin $\mathrm{C}$ (MMC).

$\square$ Normal, $\bullet \mathrm{MMC}+\mathrm{CNG}$, O MMC.
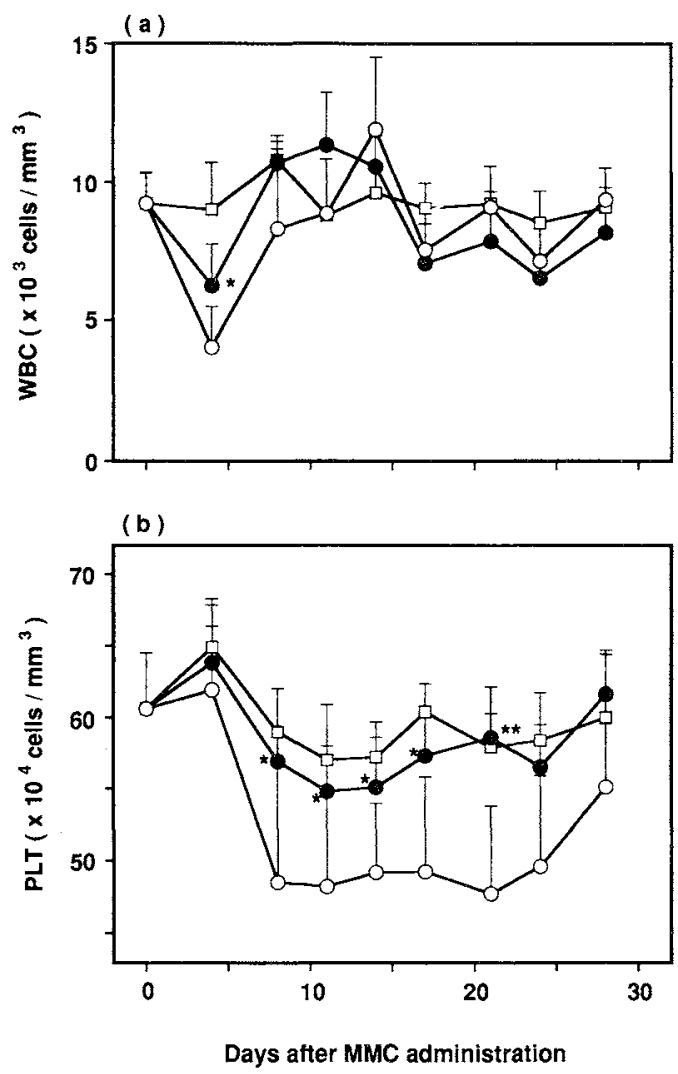

CNG $(5 \mathrm{mg} / \mathrm{kg})$ was administered ip on days 0 to 27 and MMC $(10 \mathrm{mg} / \mathrm{kg})$ was administered ip on day 0 to $\mathrm{CDF}_{1}$ mice. Each group consisted of 6 mice. ${ }^{*} P<0.05$ and ${ }^{* *} P<0.01$ in comparison with $\mathrm{MMC}$ alone.
Fig.3. Effect of CNG on WBC and PLT in mice given cyclophosphamide (CY).

$\square$ Normal, $\bullet \mathrm{CY}+\mathrm{CNG}, \mathrm{OCY}$.
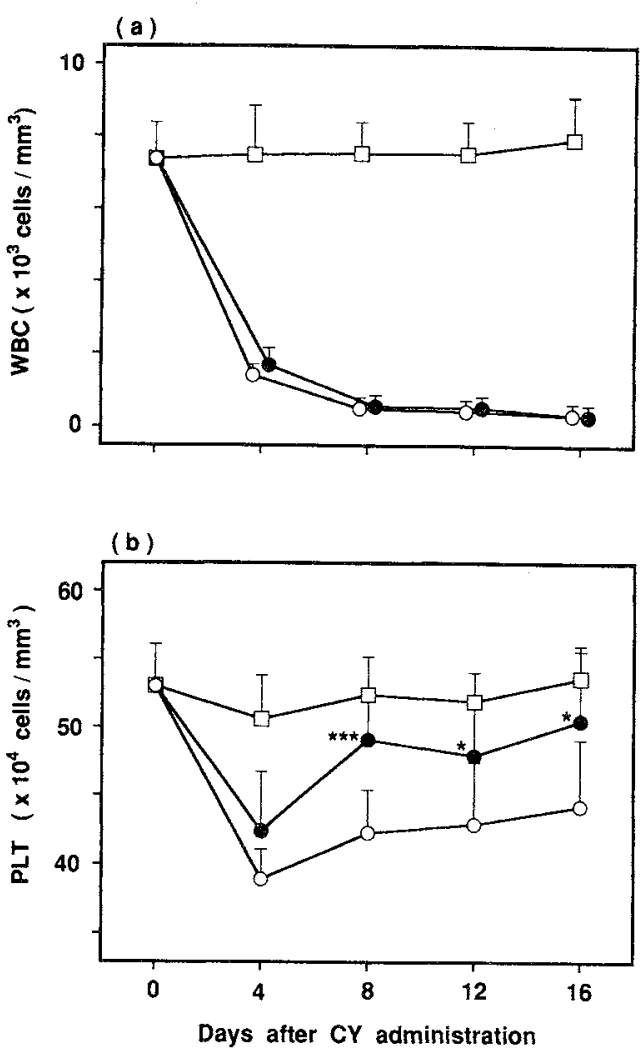

CNG $(5 \mathrm{mg} / \mathrm{kg})$ was administered ip on days 0 to 15 and $\mathrm{CY}(100 \mathrm{mg} / \mathrm{kg})$ was administered ip every other days for 7 times starting at day 0 to $\mathrm{CDF}_{1}$ mice. Each group consisted of 8 mice. ${ }^{*} P<0.05$ and $* * * P<0.001$ in comparison with $\mathrm{CY}$ alone.

on days 0,4 and 8 and $5 \mathrm{mg} / \mathrm{kg}$ of CNG daily for 28 days. As shown in Fig. 4 , the number of WBC as well as PLT was reduced by 5-Fu from days 4 to 16 , whereas these reductions were prevented by CNG and kept at normal levels up to day 28.

\section{Lymphokine Production in Cultures of Spleen and Bone Marrow \\ Cells Taken from Mice Given CNG with or without 5-Fu}

The effect of CNG on lymphokine production in cultures of spleen and bone marrow cells taken from mice given $\mathrm{CNG}$ with or without 5-Fu was investigated. The lymphokine levels which are responsible for hematopoiesis in cultured supernatants of non-adherent cells from spleen and bone marrow cells taken from mice were monitored. As shown in Fig. 5a, IL-2 was increased in mice given CNG alone in days 4 to 16 and was reduced by $5-\mathrm{Fu}$ alone in days 4 to 12 . The reduction in lymphokine levels was prevented by CNG administration.

Although IL-3 production was reduced by CNG alone on days 4 to 12 , it was augmented on day 16 . 
Fig. 4. Effect of CNG on $\mathrm{WBC}$ and PLT in mice given 5-fluorouracil (5-Fu).

$\square$ Normal, $\bullet 5-\mathrm{Fu}+\mathrm{CNG}, 0$ 5-Fu.
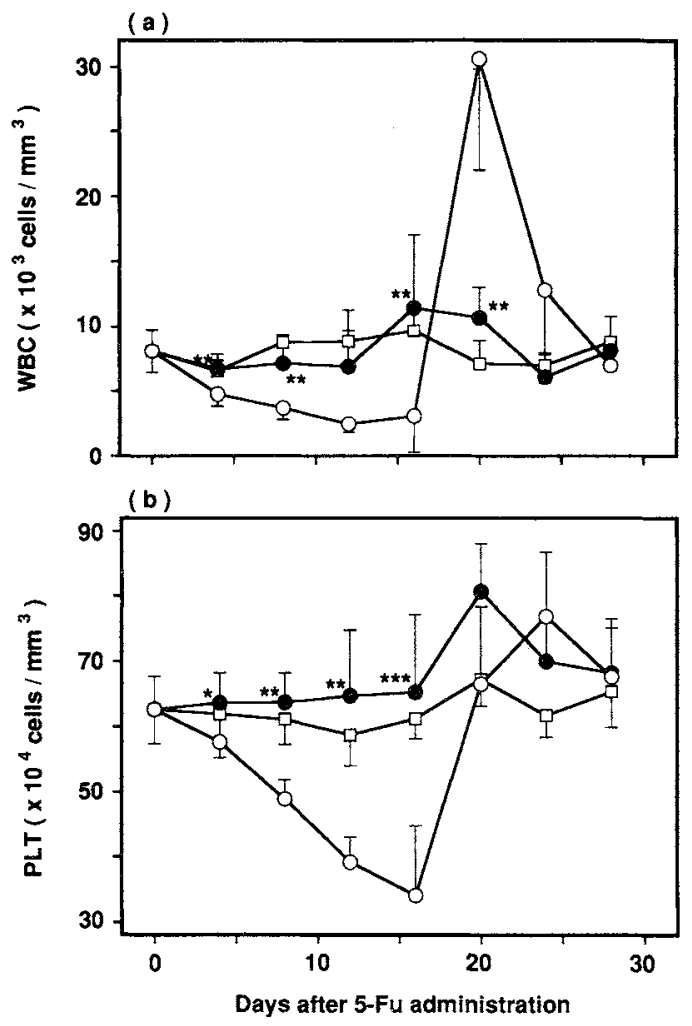

CNG $(5 \mathrm{mg} / \mathrm{kg})$ was administered ip on days 0 to 27 and $5-F u(10 \mathrm{mg} / \mathrm{kg})$ was administered ip on days 0,4 and 8 to $\mathrm{C} 57 \mathrm{BL} / 6$ mice. Each group consisted of 6 mice. ${ }^{*} P<0.05, * * P<0.01$ and $* * * P<0.001$ in comparison with $5-\mathrm{Fu}$ alone.
Fig.5. IL-2 and IL-3 production in spleen cell cultures from $\mathrm{C} 57 \mathrm{BL} / 6$ mice given $\mathrm{CNG}$.

$\square$ Normal, $\triangle \mathrm{CNG},-5-\mathrm{Fu}+\mathrm{CNG}, 0$ 5-Fu.
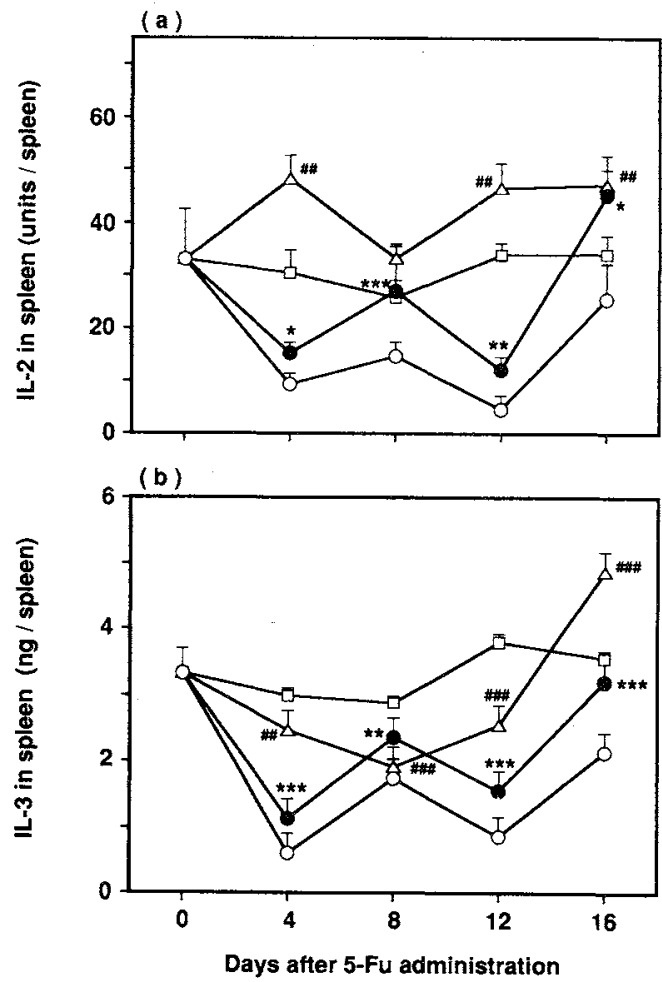

CNG $(5 \mathrm{mg} / \mathrm{kg})$ was administered ip on days 0 to 15 and $5-\mathrm{Fu}(100 \mathrm{mg} / \mathrm{kg})$ was administered ip on days 0,4 and 8 to $\mathrm{C} 57 \mathrm{BL} / 6$ mice. ${ }^{*} P<0.05,{ }^{* *} P<0.01$ and $* * * P<0.001$ in comparison with $5-\mathrm{Fu}$ alone. ${ }^{\sharp \sharp} P<0.01$ and ${ }^{\sharp \#} P<0.001$ in comparison with normal.

In mice given 5-Fu, it was reduced in days 4 to 16 and the reduction was prevented by $\mathrm{CNG}$ significantly (Fig. 5b). Production of IL-2 and IL-3 in cultured supernatants of bone marrow cells was less than $1 \mathrm{unit} / \mathrm{ml}$ and less than $10 \mathrm{pg} / \mathrm{ml}$ respectively.

Production of IL-6 in cultures of spleen and bone marrow cells is shown in Fig. 6. In spleen cells, CNG treatment reduced IL-6 levels on days 8 and 12 and the reduction was recovered on day 16 . The administration of 5-Fu reduced it markedly in days 4 to 16 whereas CNG slightly prevented the reduction. In bone marrow cells, CNG did not show marked change of IL-6 production in days 4 to 16 . The administration of 5-Fu augmented IL-6 production on day 4 and day 8 in maximum and the augmentation was observed in combined with $\mathrm{CNG}$ on day 4 in maximum and day 12 . It was normalized on day 16 by combined treatments.

\section{Discussion}

$\mathrm{CNG}$ was found as an immunomodulator which stimulates activated $\mathrm{T}$ cells to proliferate and to 
Fig. 6. IL-6 production in spleen cell and bone marrow cell cultures from $\mathrm{C} 57 \mathrm{BL} / 6$ mice given $\mathrm{CNG}$.

$\square$ Normal, $\triangle \mathrm{CNG}$, 5-Fu + CNG, O 5-Fu.
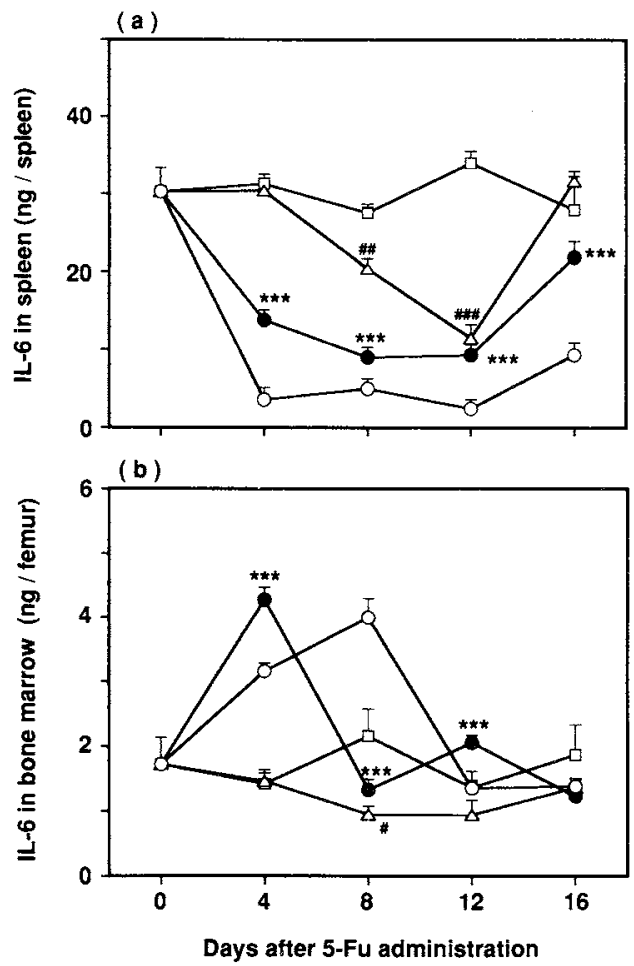

CNG $(5 \mathrm{mg} / \mathrm{kg})$ was administered ip on days 0 to 15 and $5-\mathrm{Fu}(100 \mathrm{mg} / \mathrm{kg})$ was administered ip on days 0,4 and 8 to $\mathrm{C} 57 \mathrm{BL} / 6$ mice. ${ }^{* * *} P<0.001$ in comparison with $5-\mathrm{Fu}$ alone. ${ }^{\sharp} P<0.05,{ }^{\sharp} P<0.01$ and ${ }^{\#} P<0.001$ in comparison with normal. enhance lymphokine production but does not stimulate macrophages ${ }^{24)}$. It is known that hematopoiesis is mediated by a variety of lymphokines. Except by some cytokines, there are no agents known to stimulate PLT production. In this context, the effect of CNG on PLT and WBC production in mice given antitumor agents were investigated. As shown in Figs. 2 to 4, CNG prevented PLT reduction soon after administration of antitumor agents. It should be noted that the daily administration of $\mathrm{CNG}$ immediately after start of the administration of antitumor agents improved the nadir in reduction of PLT. It has been reported that cytokines such as G-CSF, IL-1, IL-6 and SCF can stimulate to increase the number of PLT in peripheral blood and those cytokines only promote the rebound of PLT reduction induced by antitumor agents but do not improve the nadir in reduction ${ }^{3,4,9,11,15}$. In the case of $\mathrm{CNG}$, as it improved the nadir and maintained the number of PLT at almost normal level. Then the action of CNG may be different from cytokines. CNG restored the leukopenia induced by $\mathrm{MMC}$ and 5-Fu. CNG seems to be more responsible for PLT modulation than for WBC. We tested CNG with G-CSF on reductions of PLT and WBC induced by cyclophosphamide and found that CNG did not affect the effect of G-CSF in improving the number of WBC, and it did maintain the number of PLT at normal levels. It can be considered that the effect of $\mathrm{CNG}$ on hematopoiesis is due to stimulation of lymphokine production by $\mathrm{T}$ cells in hematopoietic organs. Therefore, it is possible that $\mathrm{CNG}$ may stimulate the production of lymphokines like IL-3 and IL-6 which are responsible for PLT production

but not production of cytokines like G-CSF or GM-CSF. As reported previously, it was shown that CNG suppresses macrophage function in tumor bearing mice and inhibits IL-1 production ${ }^{25)}$. The mechanism of action on macrophages is not known yet.

Lymphokine production in cultures of spleen cells as a peripheral lymphoid organ and bone marrow cells as a primary lymphoid organ of mice given $\mathrm{CNG}$ with or without 5 -Fu were monitored (Figs. 5 and 6), because the administration of CNG did not influence lymphokine levels in serum. Results indicate that CNG augmented lymphokine production by spleen cells but not IL-6 production by bone marrow cells and it was effective in preventing the reduction induced by $5-\mathrm{Fu}$ for lymphokine production. It is of note that $5-\mathrm{Fu}$ enhanced IL-6 production by bone marrow cells but not by spleen cells. The mechanism of $5-\mathrm{Fu}$ on enhancement of IL-6 production is not clear yet. However, it was reported that the proliferation of bone marrow cells is maintained for a week in high rate after the administration of $5-\mathrm{Fu}^{26}$, although the number of WBC and PLT in peripheral blood were reduced ${ }^{2,9,21,26)}$. It is likely that to restore the reduced cells by $5-\mathrm{Fu}$, the production of multipotent hematopoietic cytokines like IL- 6 could be augmented to produce a variety of progenitor cells in bone marrow.

From results reported here, it can be concluded that CNG prevents reduction of PLT induced by antitumor agents through modulation of lymphokine production. It will be reported that $\mathrm{CNG}$ enhances production of CFU-Meg depending upon Thy-1 positive cells and IL-6 and SCF in vitro and in vivo ${ }^{27)}$. It has been found that lethal toxicity of antitumor agents is reduced by $\mathrm{CNG}$, and the therapeutic indices of these substance with $\mathrm{CNG}$ are increased ${ }^{28)}$. As $\mathrm{CNG}$ is a low molecular weight and low toxicity, it 
may have usefulness in cancer chemotherapy and hematopoiesis dysfunctions, especially for diseases in which PLT are reduced.

Acknowledgment

This work was supported in part by a Grant-in-Aid for Cancer Research from the Ministry of Education, Science and Culture, Japan.

\section{References}

1) Fujisawa, M.; Y. Kobayashi, T. Okabe, F. Takaku, Y. Komatsu \& S. Itoh: Recombinant human granulocyte colony-stimulating factor induces granulocytosis in vitro. Jpn. J. Cancer Res. 77: 866 869, 1986

2) Moore, M. A. S.; R. L. Stolfi \& D. S. Martin: Hematologic effects of interleukin-1 $\alpha$, granulocyte colony-stimulating factor, and granulocyte-macrophage colony-stimulating factor in tumor-bearing mice treated with fluorouracil. J. Natl. Cancer Inst. 82: 1031 1037, 1990

3) Mizushima, Y.; T. Morikage, T. Kuwahara \& S. Yano: Effects of granulocyte colony-stimulating factor on hematopoietic injury induced by anticancer drugs in mice. J. Biol. Response. Mod. 9: 576 583, 1990

4) Mizushima, Y.; T. Kashi, K. Nakagawa, S. Monno \& S. Yano: Effects of granulocyte colony-stimulating factor, interleukin- $1 \alpha$, and interleukin- 6 on prolonged myelosuppression induced by nimustine hydrochloride in rats. $\mathbf{J}$. Immunother. 12: $98 \sim 104,1992$

5) Ganser, A.; A. Lindemann, G. Seipelt, O. G. Ottmann, F. Herrmann, M. Eder, J. Frisch, G. Schulz, R. MERTELSMANN \& D. HoELzER: Effects of recombinant human interleukin-3 in patients with normal hematopoiesis and in patients with bone marrow failure. Blood 76: 666 676, 1990

6) Gillio, A. P.; C. Gasparetto, J. Laver, M. Abboud, M. A. Bonilla, M. B. Garnick \& R. J. O’Reilly: Effects of interleukin-3 on hematopoietic recovery after 5-fluorouracil or cyclophosphamide treatment of cynomolgus primates. J. Clin. Invest. 85: $1560 \sim 1565,1990$

7) Ishibashi, T.; H. Kimura, T. Uchida, S. Kariyone, P. Friese \& S.A. Burstein: Human interleukin-6 is a direct promoter of maturation of megakaryocytes in vitro. Proc. Natl. Acad. Sci. USA 86: 5953 5957, 1989

8) Ishibashi, T.; H. Kimura, Y. Shikama, T. Uchida, S. Kariyone, T. Hirano, T. Kishimoto, F. Takatsuki \& Y. AKIYAMA: Interleukin-6 is a potent thrombopoietic factor in vivo in mice. Blood 74: 1241 1244, 1989

9) Takatsuki, F.; A. Okano, C. Suzuki, Y. Miyasaka, T. Hirano, T. Kishimoto, D. Ejima \& Y. Akiyama: Interleukin 6 perfusion stimulates reconstitution of the immune and hematopoietic systems after 5-fluorouracil treatment. Cancer Res. 50: 2885 2890, 1990

10) Asano, S.; A. OKano, K. Ozawa, T. Nakahata, T. Ishibashi, K. Kolke, H. Kimura, Y. Tanioka, A. Shibuya, T. Hirano, T. Kishimoto, F. Takaku \& Y. Akiyama: In vivo effects of recombinant human interleukin-6 in primates: stimulated production of platelets. Blood 75: 1602 1605, 1990

11) Ratchen, M. L.; T. J. Macvittie, J. L. Williams, G. N. Schwartz \& L. M. Souza: Administration of interleukin-6 stimulates multilinege hematopoiesis and accelerates recovery from radiation-induced hematopoietic depression. Blood 77: $472 \sim 480,1991$

12) Ulich, T. R.; J. del Castillo, I. K. McNiece, E. S. Yi, C. P. Alzona, S. Yin \& K. M. Zsebo: Stem cell factor in combination with granulocyte colony-stimulating factor(CSF) or granulocyte-macrophage CSF synergistically increases granulopoiesis in vivo. Blood 78: 1954 1962, 1991

13) Andrews, R. G.; G. H. KniTter, S. H. Bartelmez, K. E. Langley, D. Farrar, R. W. Hendren, F. R. Appelbaum, I. D. BernSTEIN \& K. M. ZSEBo: Recombinant human stem cell factor, a c-kit ligand, stimulates hematopoiesis in primates. Blood 78: 1975 1980, 1991

14) Molineux, G.; A. Migdalska, M. Szmitkowski, K. Zsebo \& T. M. Dexter: The effects on hematopoiesis of recombinant stem cell factor (Ligand for $\mathrm{c}-k i t$ ) administered in vivo to mice either alone or in combination with granulocyte colony-stimulating factor. Blood $78: 961 \sim 966,1991$

15) Hunt, P.; K. M. Zsebo, M. M. Hokom, A. Hornkohl, N. C. Birkett, J. C. del Castillo \& F. Martin: Evidence that stem cell factor is involved in the rebound thrombocytosis that follow 5-fluorouracil treatment. Blood 80 : $904 \sim 911,1992$

16) Hiraoka, A.; M. Yamagishi, T. Ohkubo, T. Kamamoto, Y. Yoshida \& H. Uchino: Effect of a streptococcal preparation, $\mathrm{OK}-432$, on hematopoietic spleen colony formation in irradiated mice. Cancer Res. 41: 2954 2958, 1981

17) Abe, F.; A. Matsuda, M. Schneider \& J. E. Talmadge: Effects of bestatin on myelopoietic stem cells in normal and cyclophosphamide-treated mice. Cancer Immunol. Immunother. 32: 75 80, 1990

18) Yamaguchi, F; K. Akahane, T. Takashi \& W. Tsukada: Production of colony-stimulating factor from macrophages by muroctasin. Arzneim.-Forsch./Drug Res. 38(II): $983 \sim 986,1988$ 
19) Nakajima, R.; Y. Ishida, F. Yamaguchi, T. Otani, Y. Ono, M. Nomura, T. Une \& Y. Osada: Beneficial effect of muroctasin on experimental leukopenia induced by cyclophosphamide or irradiation mice. Arzneim.Forsch./Drug Res. 38(II): 986 992, 1988

20) Nemoto, K.; Y. Sugawara, M. Ogino, T. Mae, F. Abe \& T. TAKeuchi: Myeloprotective activity of deoxyspergualin: Influence on splenic colony-forming cell injury and antitumor activity of mitomycin $\mathrm{C}$ in mice. Jpn. J. Cancer Res. 83: $789 \sim 793,1992$

21) MiYazaki, H.; Y. Yoshikai, M. TANaka, Y. Takeda, S. TAKeo \& K. Nomoto: Protective effect of SPR-901(RBS) on the decrease of peripheral leukocyte number in 5-fluorouracil-treated mice. Int. J. Immunopharmac. 14: 11 17, 1992

22) IshizuKa, M.; T. Yamashita, M. Kawatsu, T. Takeuchi, T. Katsumi \& T. Shiraishi: Conagenin, a low molecular weight immunomodulator produced by Streptomyces roseosporus, on murine tumors and platelet production. Abstracts of 18th International Congress of Chemotherapy, No. 1125, P. 310, Stockholm, 1993

23) Yamashita, T.; M. Inima, H. Nakamura, K. Isshiki, H. Naganawa, S. Hattori, M. Hamada, M. Ishizuka, T. TAKeUCHI \& Y. IITAKA: Conagenin, a low molecular weight immunomodulator produced by Streptomyces roseosporus. J. Antibiotics 44: 557 559, 1991

24) Kawatsu, M.; T. Yamashita, M. Osono, M. Ishizuka \& T. Takeuchi: T cell activation by conagenin in mice. J. Antibiotics 46: 1687 1691, 1993

25) Kawatsu, M.; T. Yamashita, M. Osono, T. Masuda, M. Ishizuka \& T. Takeuchr: Effect of conagenin in tumor bearing mice antitumor activity, generation of effector cells and cytokine production. J. Antibiotics 47: 1692 1698, 1993

26) Tsuchiya, Y.; M. Matsutani, M. Inoue, S. Sato, T. Asano \& M. Yajima: Effect of a glucan, sizofiran, on natural-killer activity of 5-fluorouracil-treated murine bone marrow cells. Cancer Immunol. Immunother. 34: $17 \sim 23,1991$

27) Katumi, T.; et al., J. Antibiotics, in preparation

28) Kawatsu, M.; T. Yamashita, M. IshizuKa \& T. TAKeUChI: Improvement for efficacy of antitumor agents by conagenin. J. Antibiotics, to submitted 